\title{
10 Paleoecology of the Paucituberculata and Microbiotheria (Mammalia, Marsupialia) from the late Early Miocene of Patagonia
}

\author{
Maria Alejandra Abello, Edgardo Ortiz-Jaureguizar, \\ and Adriana M. Candela
}

\begin{abstract}
This chapter presents a paleoecological analysis of noncarnivorous Santacrucian marsupials of the orders Paucituberculata and Microbiotheria. Different ecological niches are inferred from eslimates of body mass, diet, and locomotor behavior. Body masses were estimated using a regression analysis based on living marsupials. Possible dietary preferences were explored by an analysis of the developmeut of molar shearing crests. Inferences about locomotor behaviors of some species with well-preserved postcranial skeletal remains were derived from a published morphofunctional analysis. From the wide range of estimated body masses and diet several niches were inferred: small- to medium-sized insectivores, small- to medium-sized insectivore-frugivores, and medium- to largesized frugivores. According to our results, Paucituberculata and Microbiotheria of the Santa Cruz Formation constitute an ecologically diverse assemblage tbat inhabited forested habitats, developed under wam temperatures and seasonal rainfall. These forested habitats could have supported several non-carnivorous marsupial niches, offering diverse resources both in the spatial dimensions and in the trophic ones.
\end{abstract}

\begin{abstract}
Resumen
En este capítulo se presenta un análisis paleoecológico de los marsupiales no carnívoros del Santacrucense pertenecientes a los órdenes Pauciluberculata y Microbiotheria. Para establecer los distintos nichos ecológicos se analizaron las masas corporales, dietas y estrategias locomotoras. El tamaño corporal fue estimado a partir de una recta de regresión liuear obtenida a partir de marsupiales actuales. Las posibles preferencias dietarias fueron exploradas mediante un análisis del grado de desartollo de las crestas cortantes de los molares. Las estrategias locomotoras, en el caso de aquellas especies que poseen un esquelelo postcraneano bien preservado, fueron inferidas a partir de un análisis morfofuncional. A partir del
\end{abstract}

Early Miocene Paleabiology in Patagonia: High-Latitude Paleocommunuies of the Santa Cruz Formation, ed. Sergio F. Vizcaíno, Richard F. Kay and M. Susana Bargo. Published by Cambridge University Press. (c) Cambridge University Press 2012. análisis de los resultados de las masas corporales y la dietas, se reconocieron diversos nichos ecológicos: pequeños a medianos insectívoros, pequeños a medianos insectívoros-frugívoros y medianos a grandes fiugívoros. Nuestros resultados nos permiten concluir que los Paucjtuberculata y los Microbiotheria de la Formación Santa Cruz constituyen un agregado ecológicamente diverso que habitó zonas boscosas. desarrolladas bajo un clima cálido y con lluvias estacionales. Estas zonas habrían ofrecido una amplia diversidad de recursos tanto espaciales como tróficos para los diversos nichos ecológicos de los marsupiales no carnívoros. Nuestra reconstrucción paleoambiental es compatible con la exisrencia de heterogeneidad ambiental durante el Santacrucense, inferencia esta derivada de otros indicadores climático-ambientales.

\subsection{Introduction}

During the Cenozoic, a high diversity of metatherians occupied a broad range of ecological niches in South America. This array mcluded medium to large carnivorous and carnivorousomnivorous (i.e. Sparassodonta; Prevosti et al., Chapter 11). small granivorous (e.g. polydolopimorphian Argyrolagoidea; Goin et al., in press), and several small to medium insectivorous and insectivorous-frugivorous species (e.g. didelphimorphian Didelphidae, Paucituberculata; Goin et al., in press, Dumont et al., 2000). All of the larger taxa are now extinct, and a few of the small- to medium-sized insectivorous, insectivorousfiugivorous, and camivorous taxa (microbiotherians, paucituberculatans, and dideiphids) survive to the present.

Paucituberculata and Microbiotheria are two major Marsupialia clades (Fig. 10.1). As a result of all current phylogenies (e.g. Amrine-Madsen et al., 2003; Horovitz and Sánchez-Villagra, 2003; Phillips et al., 2006; Asher ct al., 2004; Nilsson et al., 2004; Beck, 2008; Meredith et. al., 2008). there is consensus on the close affinities between the extant microbiotheriid Dromiciops gliroides and the Australasian marsupials (Australidelphia; Szalay, 1982. 1994). However. the position of $D$. gliroides within Australidelphia is still controversial (Nilson et al., 2010). On the other hand, most 


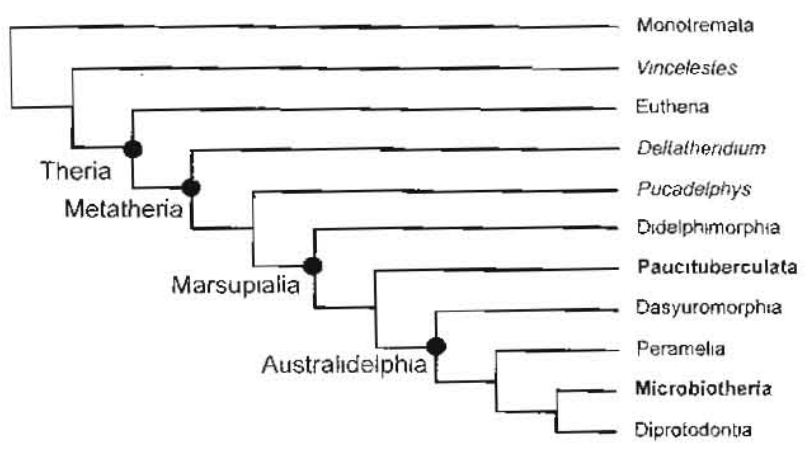

Fig. 10.1. Phylogenetic tree showing the relationships of living marsupial orders (modified from Horovitz and Sánchez-Villagra, 2003).

phylogenetic studies based on molecular or combined data (e.g., Nilson et al., 2004; Asher et al., 2004; Beck, 2008; Meredith et al., 2008), as well as some morphological studies based on cranial, postcranial, and soft tissue anatomy (Horovitz and Sánchez-Villagra, 2003), indicate that Paucituberculata is the sister group of Australidelphia.

Microbiotherians and paucituberculatans are poorly represented in present-day ecosystems (Flores, 2006a, b; Patterson, 2007; Patterson and Rogers, 2007). The only extant microbiotherian is the so-called "monito del monte" (Dromiciops gliroides), a small insectivorous marsupial endemic to the temperate forests of southern Chile and Argentina, associated with the southern beech forests (Nothofagus) and South American mountain bamboos (Chusquea) (Hershkovitz, 1999). Dromiciops gliroides is the only South American marsupial reported to exhibit deep torpor or hibernation (Greer, 1966; Bozinovic et al., 2004). In the summer season this species is active during the night, being a common mammal of the understory stratum (Rodríguez-Cabal et al.. 2008).

The living Paucituberculata include five species that are grouped in the genera Caenolestes, Lestoros, and Rhyncholestes, all belonging to Caenolestidae ("shrew opposums"). This clade has a disjunct Andean distribution that ranges from Venezuela to northern Peru (Caenolestes; Albuja and Patterson, 1996), central Peru and Bolivia (Lestoros inca; Anderson, 1997; Ramirez et al., 2007) and southern Chile and Argentina (Rhyncholestes; Patterson and Gallardo, 1987; Birney et al., 1996). Caenolestids have a wide latitudinal and altitudinal (up to 4000 meters above sea level) distribution, spanning several biomes including Páramo, Montane forest, and Valdivian forest. Extant caenolestids are snall shrew-sized marsupials, which inhabit moist and dense vegetated microhabitals (Kirsh and Waller, 1979; Kelt et al., 1994). The scanty ecological data reported in the literature indicate that caenolestids have a cursorial-leaping locomotion, and a primarily insectivorous diet (Kirsh and Waller, 1979; Barkley and Whitaker, 1984, Patterson and Gallardo, 1987; Patterson, 2007).
The fossil record of Paucituberculata and Microbiotheria indicates that these marsupials had a wider geographic distribution and higher taxonomic diversity than those of the present (Abello, 2007; Goin et al., in press). The oldestknown Paucituberculata and Microbiotheria date from the Paleocene and include forıns such as the paucituberculatan Bardalestes Goin, Candela, Abello and Oliveira, 2009 (Itaboraian Age, Argentina; Goin et al., in press) and the microbiotherian Mirandatherium (Paula Couto, 1952) from Brazil (Itaboraian Age; Goin et al., in press). Both groups achieved their highest taxonomic diversity in the Early Miocene Colhuehuapian and Santacrucian Ages, but the inferred cladogenetic events that gave rise to the Miocene forms seem to have occurred during the Oligocene (Abello, 2007; Goin $e t$ al., 2010). By the Early Miocene, microbiotherians are represented by nine species belonging to Microbiotheriidae. At the same time, paucituberculatans are represented for 23 species grouped among Caenolestidae, Pichipilidae, Palaeothentidae, and Abderitidae.

Despite the abundant representation of small marsupials (particularly paucituberculatans) in the Early Miocene (Bown and Fleagle, 1993; Abello, 2007), they are mainly known by mandibular and maxillary remains and isolated teeth. Consequently, the reconstructions of certain paleoecological aspects (e.g. body size, diet) have been derived from the study of dental remains.

Several ecological niches have been identified among Paucituberculata (Dumont et al.. 2000): small insectivores (Caenolestidae and Pichipilidae), small- to medium-size insectivore-frugivores (Palaeothentidae), and small- to medium-size frugivores (Abderitidae). As yet only two specimens including postcranial and cranial remains are reported for Pancituberculata (Abello and Candela, 2010). These were referred to two palaeothentid species, Palaeothentes minutus Ameghino, 1887 and Palaeothentes lemoinei Ameghino, 1887, from the late Early Miocene (Santa Cruz Formation). Curso-saltatorial locomotor strategies were inferred for both species (Abello and Candela, 2010).

In this chapter we summarize previous paleoecological studies of Santacrucian Paucituberculata, and present the results of a new paleoecological analysis of Santacrucian Microbiotheria. Additionally, we evaluate the paleoenvironmental significance of non-carnivorous Miocene marsupials.

\subsection{Santacrucian paucituberculatans and microbiotherians}

During the South American Miocene, paucituberculatans and microbiotherians coexisted with other metatherians such as Sparassodonta, polydolopimorphian Argyrolagoidea, and Didelphimorphia. Paucituberculatans occur in most Miocene assemblages, but Argyrolagidae and Didelphimorphia are rare or absent as is the case for the late Early Miocene fauna of Santa 


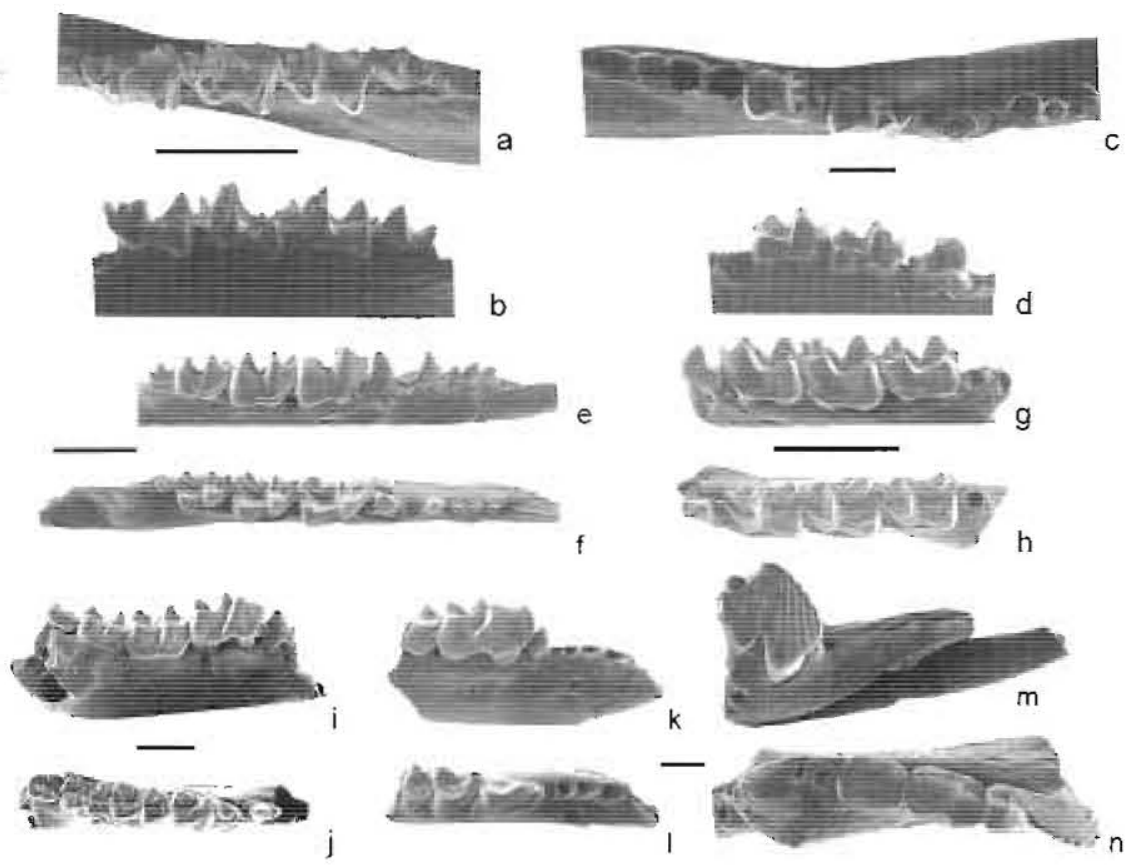

Fig. 10.2. Dentition of selected Pauciruberculata and Microbiotheriidae species of the Santa Cruz Formation. a, b, Microbiotherium acicula (MACN-A 5727) left mandibular fragment with $m 1-4$ in labia! (a) and occlusal (b) views. c, d. Microbiothertum gallegosense (type AMNH 9591) right mandibular fragment with p3-m3 in labial (c) and occlusal (d) views. e, f. Stilotherium dissimile (rype MACN-A 8464) right mandibular fragment with $\mathrm{i} 2$, i3 alveolous, three one-roored teeth and $\mathrm{p} 2-\mathrm{m} 4$ in labial (e) and occlusal (f) views. $\mathrm{g}$, h, Phonocdromus gracilis (rype MACN-A 8457). left mandibular fragment with p3-m3 in labial (g) and occlusal (h) views. i, j, Palaeothentes minutus (MACN-A 5591-5518a), right mandibular fragment with $\mathrm{p} 3-\mathrm{m} 4$ in labial (i) and occlusal (j) views. $\mathrm{k}, \mathrm{l}$, Acdestis owenii (type MACN-A 1379) mandibular fragment with $\mathrm{i} 2$, fonr alveoli of one-rooted teeth, complete $\mathrm{p} 3-\mathrm{m} 1$ and $\mathrm{m} 2$ trigonid in labial ( $\mathrm{k}$ ) and occlusal (l) views. $\mathrm{m}$, $\mathrm{n}$. Abderites meridionalis, (m) (MLP 55-XIf-13-145) mandibular fragment with il, four alveolous of one-rooled teeth and $\mathrm{p} 3-\mathrm{m} 1$ in labial view, (n) (type MACN-A 12) mandibular fragment with m $\mathrm{l}-3$ and $\mathrm{m} 4$ alveolous in occlusal view. Scale bar, $2 \mathrm{~mm}$.

Cruz beds. To date, microbiotherians (Fig. 10.2a-d) and paucituberculatans (Figs. 10.2e-n and 10.3) are the only non-carnivorous metatherians recorded in the Santa Cruz Formation. Metatherians of this formation were first described by Ameghino (1887, 1891). Sinclair (1906) and Marshall (1976a, 1980, 1982) made significant contributions to the knowledge of the diversity of Santacrucian paucituberculatans and microbiotheriids. Recent revisions inciude those of Bown and Fleagle (1993), Tauber (1997), Abello (2007), and Abello and Rubilar-Rogers (in press). An updated taxonomic list and the records of paucituberculatans and microbiotheriids from localities of the Santa Cruz Formation are presented in Appendix 10.1.

\subsection{Materials and methods}

The material studied is listed in Appendix 10.2.

\subsubsection{Abbreviations}

The generalized metatherian dental formula is: $\mathrm{l} / \mathrm{i} 5 / 4, \mathrm{C} / \mathrm{c}$ $1 / 1, \mathrm{P} / \mathrm{p} 3 / 3, \mathrm{M} / \mathrm{m}$ 4/4.

\section{Institutional abbreviations}

MACN, Museo Argentino de Ciencias Naturales "B. Rivadavia," Buenos Aires, Argentina. MACN-A, Colección Nacional Ameghino.

MLP, Museo de La Plata, La Plata, Argentina.

AMNH, American Museum of Natural History, New York, EEUU.

MPM-PV, Museo Regional Provincial Padre Manuel Jesús Molina, Río Gallegos, Argentina.

\subsubsection{Methodology}

To estimate body masses and infer dietary preferences of Santacrucian non-camivorous marsupials, we follow the methodologies of Dumont et al. (2000). In the context of an analysis of dietary preferences of Paucituberculata, Dumont et al. (2000) studied all available Santacrucian species. Here we summarize the results of these dietary reconstructions, and apply the same methodology to the Santacrucian Microbiotheriidae. In contrast to Dumont et al. (2000), we follow Abello and Rubilar-Rogers (in press) in considering A. meridionalis Ameghino, 1887 to be a different species from the Colhuehuapian Abderites crispus Ameghino, 1902. 

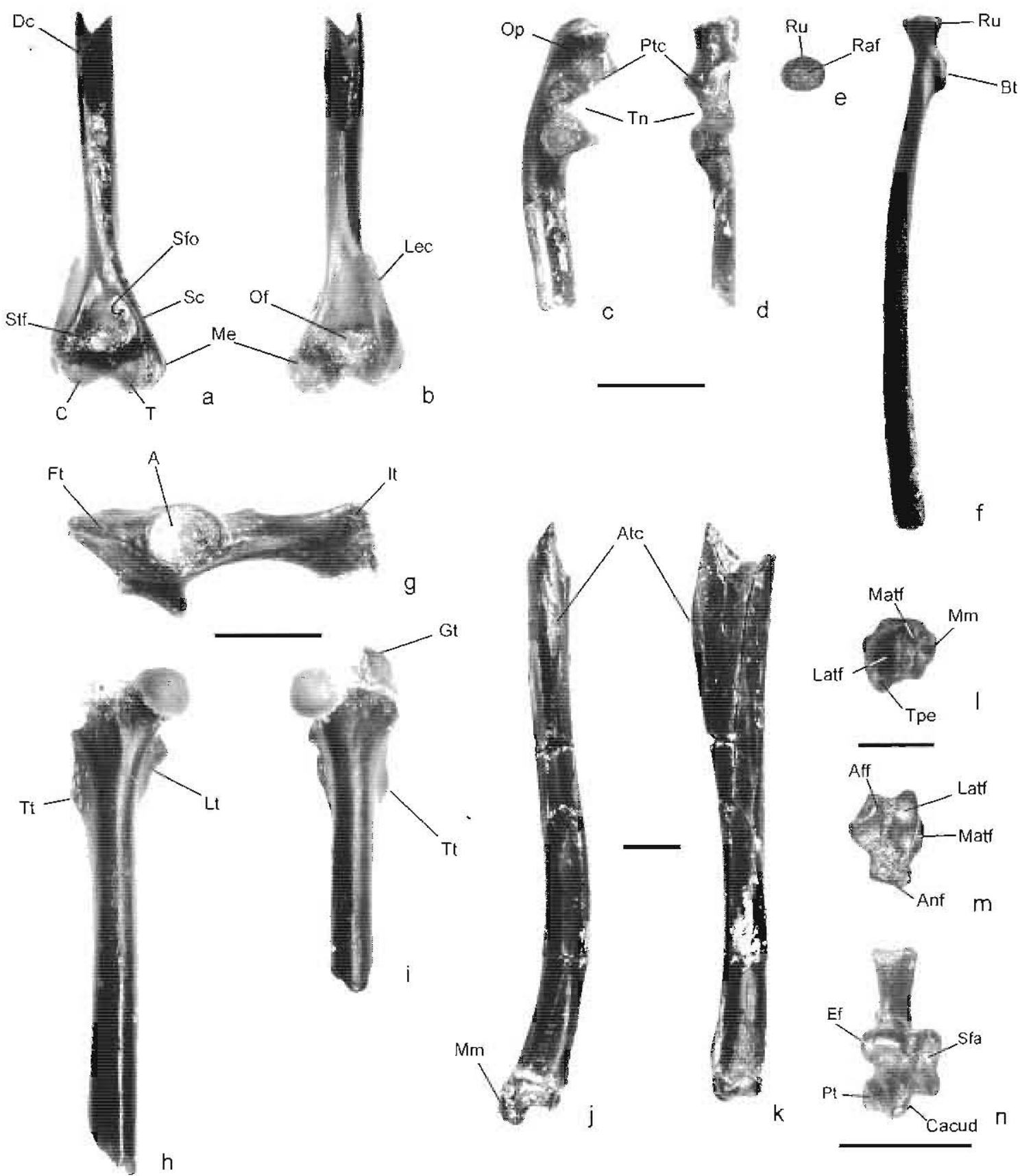

$\mathrm{k}$

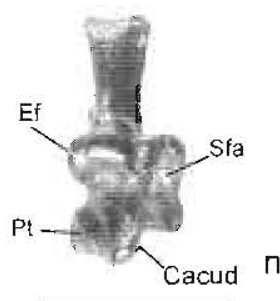

Fig. 10.3. Postcranial skeleton of Palaeothentes species. Palaeothentes minutus: a, b, right humerus (MACN-A 5619-5639c) in anterior (a) and posterior (b) views; c, d, right ulna (MACN-A 5619-5639e) in lateral (c) and anterior (d) views. e, f, Right radius (MACN-A 5619-5639d) in proximal (e) and medial (f) views. g. Pelvis (MACN-A 5619-5639f) in lateral view: h, right femur (MACN-A 5619-5639g) in anterior view: $i$, left femur (MACN-A 5619-5639h) in anterior view. Palaeothentes lemoinei (MPM-PV 3494): j, k. left tibia in anterior (j) and lateral (k) views; 1 , right tibia in distal view; m, right astragalus in dorsal view. Palaeothentes minutus (MACN-A 5619-5639i); n, right calcaneum in dorsal view. Scale bar, $4 \mathrm{~mm}$. Abbreviations: A. acelabulum; Aff, astragalofibular facet; Auf, asiragalouavicular facet; Atc, anterior tibial crest; Bt, bícipilal tuberosity; C, capitulum; Cacud, cuboid facet distal half; Dc, deltopectoral crest; Ef, ectal facet; Ft, femoral tubercle; Gt, great trochanter; It, ischial tuberosity; Latf, lateral astragalotibial facet; Lec, lateral epicondylar crest; Lt. icsser trochanter; Matf. medial astragalotibial facet; Me. medial epicondyle: Mm, medial mallcolus; Of, olecranon fossa: Op, olecranon process; Pt, peroneal tubcrcle; Ptc, proximal trochlear crest; Raf, radial articular facet for the capitulum; Ru, radio-ulnar facet; Sc, supracondyloid crest; Sfa, sustentacular facet; Sfo, supracondyloid foramen; Stf, supratrochlear foramen: T, trochlea; Tn. trochlear notch; Tpe, tibial posterior extension; $\mathrm{Tt}$, third trochanter. 
Regarding the locomotor habits of Palaeothentes species, we present here a synthesis of Abello and Candela's (2010) main results.

Body mass Body masses were estimated from the occlusal area (mesiodistal length $\times$ labiolingual breadth) of the second lower molar, using the linear regression equation

ln body mass $=2.419+(1.727 \times \ln \mathrm{m} 2$ area $)$

derived by Dumont et al. (2000) for living marsupials. This equation included 27 extant marsupial species whose body masses range from approximately 10 to $1500 \mathrm{~g}$, a wide range encompassing that of Santacrucian marsupials.

Locomotion and use of the substrate To assess the locomotor strategies of Palueothentes minutus and P. lemoinei, Abello and Candela (2010) performed a morphofunctional analysis based on comparisons with living South American marsupials.

Palaeothentes minutus (MACN-A 5619-5639a-i) is the most inportant specinnen available, being represented by the humerus, radius, ulna, femur, pelvis, and calcaneum (Fig. 10.3a-i, n). The postcranium of $P$. lemoinei (MPM-PV 3494) preserves the humerus, ulna, pelvis, tibiae, and astragalus (Fig. $10.3 \mathrm{j}-\mathrm{m}$ ). The postcranial features with functional significance, preserved in these fossils, were compared to those of extant marsupials having various locomotor behaviors. Abello and Candela (2010) evaluated traits functionally related to different movements (e.g. flexion/extension, pronation/supination). In this context, special attention was paid in the analysis of articular surfaces (e.g. elbow, cmroastragalar, and hip joints) and areas of muscular attachment. Cuenolestes fuliginosus and the didelphids Metachirus nudicaudatus and Monodelphis dimidiata were considered as terrestrial model species. The didelphid Didelphis aurita and the microbiotheriid Dromiciops gliroides were included as scansorial and arboreal models, respectively.

Feeding habits The dietary habits of the Santacrucian microbiotheriids were investigated following the method of dietary reconstructions proposed by Strait (1993a, b). This approach relies on the assumption that the development of sheariug crests on the molars should reflect the physical properties of the foods that must be comminuted (Strait, 1993b; Kay and Hylander. 1978).

Two molar shearing ratios are calculated to discriminate frugivorous from faunivorous small-bodied taxa in a comparative framework with extant manmals whose dietary preferences are well known. Both ratios consider the sum of six shearing crests (crests 1-6 of Kay and Hiiemae. 1974; Fig. 10.4), and two size surrogates: $m 2$ length and the square root of $\mathrm{m} 2$ area. The shearing ratio based on area

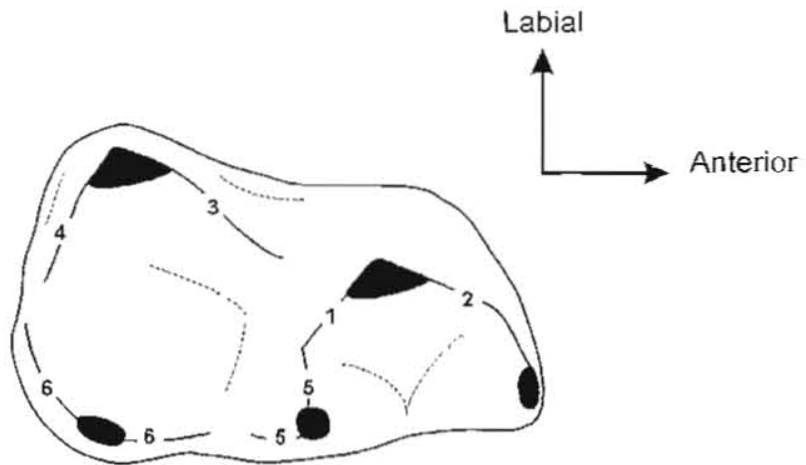

Fig. 10.4. Occlusal view of left lower second molar showing the shearing crests I-6 (Kay and Hiiemae, 1974) measured in this study.

(SRA) is the sum of lengths of crests $1-6$ divided by the square root of tooth area, and the shearing ratio based on length (SRL) is the sum of lengths of crests $1-6$ divided by molar length.

The present analysis is based on those performed by Dumont et al. (2000) for paucituberculatans, who included the following living marsupials as models: four insectivores (the paucituberculatans Lestoros inca and Caenolestes caniventer, the dasyurids Antechinus stuartii and Sminthopsis crassicaudata), and two frugivores (the petaurids Petaurus breviceps and Acrobates pygmaeus). To broaden the comparative sample of extant marsupials, we included here the insectivorous microbiotheriid Dromiciops gliroides (Patterson and Rogers, 2007, and references (herein).

Living marsupials, especially those of the Australasian region, have a broad dietary diversity including a wide range of food, such as vertebrate and invertebrate prey, vegetative and reproductive tissues of plants, plant exudates, and fungi (Hume, 2006). For the living marsupials several feeding categories may be established (Lee and Cockburn, 1985); however. the definition of strict trophic categories is imprecise (Vieira and Astúa de Moraes, 2003). Taking into account this constraint, we have followed Dumont et al. (2000) and used broad dietary categories to infer the diet of the Santacrucian marsupials. These authors used two categories. faunivores and frugivores, but we have preferred to use "insectivores" instead of "faunivores" for two reasons: (1) faunivores is an equivocal term, because it has been used to refer to those carnivorous mammals that eat vertebrates (e.g. Hume, 2003), as well as to those that eat invertebrates (e.g. Heesy, 2008); and (2) all the living species used by Dumont et al. (2000) to represent "faunivores" are actually insectivores (= insectivore/omnivore of Lee and Cockburn, 1985) because they feed primarily on arthropods (whicb may be consumed as adults or juvenile stages) but their diet may include, in some cases, vegetable 
matter and fungi. On the other hand, the marsupials used by Dumont et al. (2000) to represent frugivores feed mainly on plant materials, such as nectar, pollen, exudates (gum, sap, and sugar encrustations produced by sap-sucking insects and known as "manna") and fruits, but their diet may be complemented with insects when seasonally available. In this context, this category includes those exudate feeders/ insectivores and frugivores/omnivores of Lee and Cockburn (1985). Finally, Dumont et al. (2000) also found a third feeding category (i.e. "mixed feeders" or "frugivorous-faunivorous"), formed by those marsupiais that emerge as frugivorous or "faunivorous" depending on shearing ratio (i.e. the caenolestid Stilotherium dissimile Amegino, 1887, the abderitid Pitheculites minimus Ameghino, 1902, and the palaeothentid Acdestis lemairei Bown and Fleagle, 1993). We prefer to use insectivore-frugivore because both "mixed feeders" and "frugivorous-faunivorous" are ambiguous terms. The former is more frequently used to designate those herbivorous mammals that are intermediate between grazers and browsers, ealing both browse and grass (e.g. the red deer Cervus elaphus, the impala Aepyceros melampus, the nyala Tragelaphus angasi: Staver et al., 2009). The difficulty with the latter is the ambiguity in the usage of faunivore, as explained above.

Measurements of lower second molar maximum length, maximuin width, and the lengths of six of its shearing crests were made on a Carl Zeiss Microscope using a measurement module (Axiovision 4.2 and 4.6).

\subsection{Results}

\subsubsection{Body mass}

The estimated body masses were $20 \mathrm{~g}$ for Microbiotherium acicula, $40 \mathrm{~g}$ for $M$. patagonicum, $61 \mathrm{~g}$ for $M$. tehuelchum, $147 \mathrm{~g}$ for $M$. gallegosense, and $487 \mathrm{~g}$ for Abderites meridionalis. Table 10.1 shows the current body mass estimations for microbiotherians and A. meridionalis, and those previously presented by Dumont $\mathrm{et} \mathrm{cl}$. (2000) for paucituberculatans, with the exception of A. meridionalis (see Methodology).

\subsubsection{Locomotion and use of substrate}

The results of comparative analysis with extant marsupials showed that several postcranial features of Palaeothentes species resemble those of modern curso-saltatorial forms

Table 10.1. Body mass estimates and diet of Santacrucian Microbiotheriidae and Paucituberculata

\begin{tabular}{|c|c|c|c|c|}
\hline & Sample size & $\mathrm{m} 2$ area $\left(\mathrm{mm}^{2}\right)$ & Body mass & Diet \\
\hline Microbiotheria & & - & & \\
\hline \multicolumn{5}{|l|}{ Microbiotheriidae } \\
\hline Microbiotherium acicula & 1 & 1.38 & $20 \mathrm{~g}$ & Insectivorous \\
\hline Microbiotherium patagonicum & 1 & 2.07 & $40 \mathrm{~g}$ & Insectivorous \\
\hline Microbiotherium tehuelchum & 1 & 2.66 & $61 \mathrm{~g}$ & Insectivorous \\
\hline Microbiotherium gallegosense & 1 & 4.44 & $147 \mathrm{~g}$ & Insectivorous-frugivorous \\
\hline \multicolumn{5}{|l|}{ Paucituberculata } \\
\hline \multicolumn{5}{|l|}{ Caenolestidae } \\
\hline Stilotherium dissimile & 3 & 1.48 & $37 \mathrm{~g}$ & Insectivorous-frugivorous \\
\hline \multicolumn{5}{|l|}{ Pichipilidae } \\
\hline Phonocdromus gracilis & 2 & 1.04 & $28 \mathrm{~g}$ & Insectivorous \\
\hline \multicolumn{5}{|l|}{ Palaeothentidae } \\
\hline Palaeothentes aratae & 13 & 11.34 & $860 \mathrm{~g}$ & Frugivorous \\
\hline Palaeothentes minutus & 112 & 3.06 & $82 \mathrm{~g}$ & Insectivorous \\
\hline Palaeothentes intermedius & 30 & 4.67 & $192 \mathrm{~g}$ & Insectivorous \\
\hline Palaeothentes lemoinei & 28 & 7.18 & $425 \mathrm{~g}$ & Insectivorous \\
\hline Palaeothentes pascuali & 6 & 2.25 & $38 \mathrm{~g}$ & Insectivorous \\
\hline Acdestis owenii & 113 & 6.71 & $344 \mathrm{~g}$ & Frugivorous \\
\hline Acdestis lemairei & 18 & 5.13 & $256 \mathrm{~g}$ & Insectivorous-frugivorous \\
\hline \multicolumn{5}{|l|}{ Abderitidae } \\
\hline Abderites meridionalis & 15 & 8.86 & $487 \mathrm{~g}$ & Frugivorous \\
\hline
\end{tabular}

The sample size and mean $\mathrm{m} 2$ area $\left(\mathrm{mm}^{2}\right)$ from which the body mass was reconstructed are presented. Inferred diet (Diet) is based on shearing ratio and body mass data. 
such as Caenolestes fuliginosus and Metachirus nudicaudatus (Abello and Candela, 2010). Characteristics of the forelimbs include, among other features, a deep and high humeral trochlea (Fig. 10.3a), a deep olecranon fossa (Fig. 10.3b), and mediolaterally broad proximal trochlear crest (Fig. $10.3 \mathrm{c}, \mathrm{d})$. These featnres indicate a well-stabilized elbow joint. The short lateral epicondylar crest (Fig. 10.3b) and the suboval radial head (Fig. 10.3e) suggest that pronation-supination was limited (Abello and Candela. 2010: 1520). The pelvis, better preserved in $P$. minutus, shows a restrictive acetabulum (i.e. tightly articulating; Szalay and Sargis, 2001), lengthened ischium, and prominent femoral tubercle as well as ischial tuberosity (Fig. 10.3g). The morphology of the pelvis indicates a high stability at the ilio-femoral joint and an increased mechanical advantage of the flexors and extensors of the hip (i.e. rectus femoris and hamstring muscles), which are well developed in saltatorial species (Argot, 2003a). The greater trochanter of the femur projects beyond the proximal surface of the femoral head (Fig. 10.3i), indicating that the gluteal muscles were favorably positioned to produce fast extension at the hip joint, as occurs in agile and leaping species. Additionally, the hind limbs of Palaeothentes species, like those of curso-saltatorial forms, have features associated with marked stability for flexion and extension in the parasagittal plane. Among these functionally significant traits are the right angle between the medial and lateral astragalotibial facets at the cruroastragalar joint (Fig. 10.3l, m), and the conformation of the transverse tarsal joint, characterized by the distal and proximal calcaneocuboid facet forming a right angle (Fig. 10.3n).

(a)

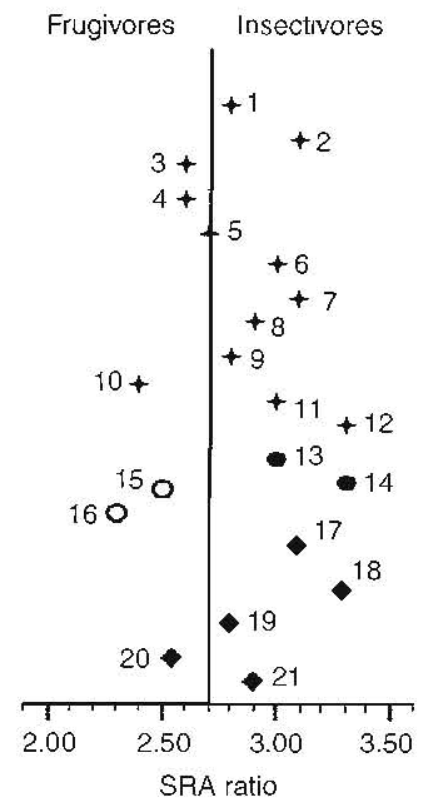

(b)

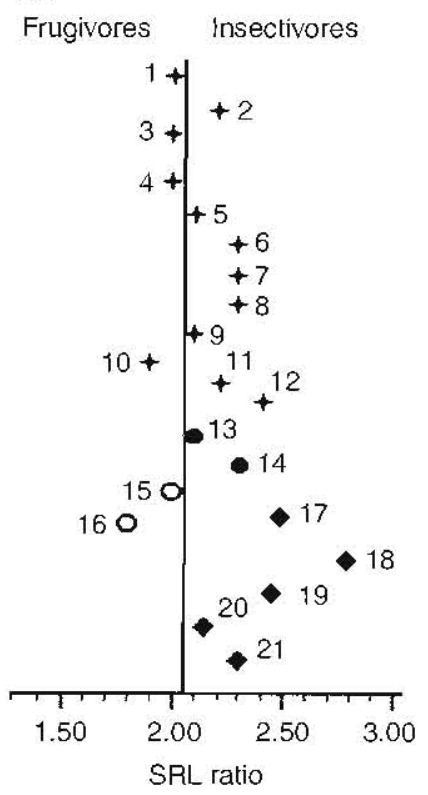

\subsubsection{Feeding habits}

Plots of SRL and SRA show the separation between extinct and extant frugivorous and insectivorous species (Fig. 10.5). Both ratios indicate that most extinct microbiotheriids were insectivorous. Microbiotherium acicula is the microbiotheriid with the highest SRA and SRL values, equaling the living insectivorous Caenolestes caniventer and Sminthopsis crassicaudata in SRA ratio. The SRL value of Microbiotherium patagonicum is close to that estimated for Dromiciops gliroides, while $M$. tehuelchum and $M$. gallegosense present lesser SRL values than $D$. gliroides and $M$. acicula, indicating a less shearing development in these species. Microbiotherium gallegosense has an SRA value comparable to those of the living Australian frugivores Petaurus breviceps and Acrobates pygmaeus. However, $M$. gallegosense clusters with the modern insectivores based on SRL ratio (Fig. 10.5b).

Among paucituberculatans, three species (Abderites meridionalis, Acdestis owenii Ameghino, 1887, and Palaeothentes aratae Ameghino, 1887) cluster with modern frugivores on the basis of SRA and SRL ratios. Conversely, Phonocdromus gracilis Ameghino, 1894 (Fig. 10.2g, h) and the palaeothentids Palacothentes pascuali Bown and Fleagle, 1993, P. minutus, P. intermedius Ameghino, 1887, and $P$. lemoinei cluster with the living insectivores. Finally, the caenolestid Stilotherium dissimile (Fig. 10.2e, f) and the palaeothentid Acdestis lemairei are classified as frugivorous or insectivorous depending on shearing ratio (i.e. as insectivore-frugivore, Fig. 10.5a, b).

Fig. 10.5. Partition berween frugivorous and insectivorous taxa based on SRA (a) and SRL (b) ratios. Paucituberculatans (crosses). petaurids (lilled circles), dasyurids (open circles). microbiotherids (diamonds). Species are: 1, Stilotherium dissimile;

2, Phonocdromus gracilis; 3 , Abderites meridionalis; 4, Acdestis owenii; 5, Acdestis lemairei; 6, Palaeothentes minutus:

7. Palaeothentes pascuali; 8 , Palaeothentes imermedius;

9, Palaeothentes lemoinei; 10, Palaeothentes aratae; 11, Lestoros inca; 12. Caenolestes caniventer; 13, Antechinus stuartii;

14, Sninthopsis crassicaudata; 15, Petaurus breviceps;

16, Acrobates pygmaeus; 17, Dromiciops gliroides;

18, Microbiotherium acicula; 19 , Microbiotherium patagonicum:

20, Microbiotherium gallegosense; and 21, Microbiotherium tehuelchum. 


\subsection{Discussion}

\subsubsection{Body mass}

In a study of extant Neotropical marsupials, Birney and Monjeau (2003) analyzed the distribution of body size among species and established three size categories: (a) small-sized (less than $100 \mathrm{~g}$ ); (b) medium-sized (from 100 to $499 \mathrm{~g}$ ); and (c) large-sized (500 g or more). Taking into account these size categories, we found that Santacrucian microbiotheriids were mainly small-sized, with estimated body masses ranging from $20 \mathrm{~g}$ in Microbiotherium acicula to $147 \mathrm{~g}$ in $M$. gallegosense (Fig. 10.2c, d). Santacrucian paucituberculatans show a much greater body-mass range, extending from $13 \mathrm{~g}$ in Phonocdromus gracilis to $800 \mathrm{~g}$ in Palaeothentes aratae, and with more than half of the species being small- to medium-sized (Table 10.1).

Throughout the Cenozoic, most South American metatherians were small- to medium-sized (see Goin, 2003). In extant fauuas, small- to medium-sized marsupials represent about $90 \%$ of the marsupial fauna of the Americas (see Birney and Monjeau, 2003), and they are also abundant in the marsupial fauna of Australasia (Dickman and Vieira, 2006). Our results are in agreement with this pattern, because $52 \%$ of the Santacrucian marsupial species are small- to medium-sized (nine paucituberculatans plus four microbiotherian species; see Table 10.1), and 48\% are large (one paucituberculatan species plus 11 sparassodont species; see Table 10.1 and Prevosti et al., Chapter 11).

Santacrucian paucituberculatans and microbiotheriids show a body mass overlap in the small and medium size categories (Fig. 10.6a, c). Nevertheless, the differential use of space and food resources may have miuimized or avoided competition among species of similar body mass, as in extant marsupial assemblages (Charles-Dominique et al., 1981; Charles-Domiuique, 1983: Vieira and Monteiro-Filho, 2003).

\subsubsection{Locomotion and use of the substrate}

Locomotor strategies constitute an important dimension of a species' niche. For extinct mammals, locomotion may be inferred from fossil postcranial remains, and have implications for species paleoecology. Unfortunately, only two skeletons of non-carnivorous Santacrucian marsupials are known. Both skeletons (pertaining to two different palaeothentid species) were recently analyzed by Abello and Candela (2010) who paid particular attention to the reconstruction of locomotor pattern. As noted earlier, in terms of functionally significant features, the major similarities were found with the extant marsupials Caenolestes fuliginosus and Metachirus nudicaudatus. The latter is the most terrestrial didelphid (Miles et al., 1981; Delciellos and Vieira, 2006, 2009). This marsupial inhabits a wide range of forest habitats (Miranda et al., 2009), from open scrub
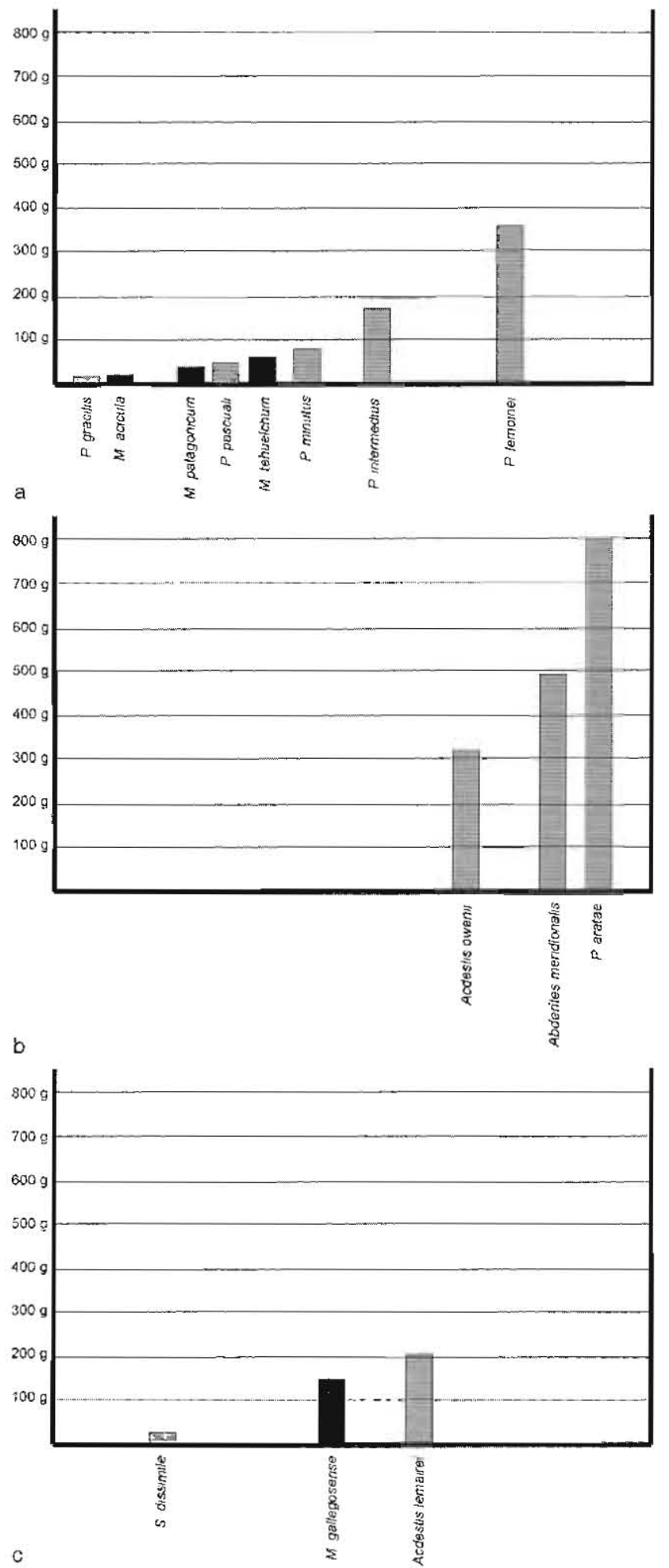

Fig. 10.6. Body mass averages of insectivorous (a), frugivorous (b), and insectivorous-frugivorous (c) non-camivorons marsupials of Santa Cru Foruation. Gray bars: paueituberculatans; black bars: microbiotheriids. Values from Table 10.1. 
vegetation (Miles et al., 1981) to lowland and hillside woodlands (Moraes, 2004). In the wild it was observed bonnding on the ground, swiftly negotiating obstacles at high speed (Miles et al., 1981). Caenolestes species occur in the Andean highlands biomes such as Montane and Clond forests, and Páramo. In these biomes caenolestids inhabit forests with or without dense undergrowth, and the grassland-forest ecotone (Kirsh and Waller, 1979; Albuja and Patterson, 1996). Caenolestes and its relative Lestoros cau leap at high speed using anterior and posterior limbs simultaneously (Kirsh and Waller, 1979).

Locomotor behaviors of $M$. nudicaudatus and caenolestids have clear anatomical correlates in their postcranial skeletons (Grand, 1983; Argot, 2003a, b), a particularly important aspect for functional interpretations in fossil species. Palaeothentes species exhibit enhanced joint stability and parasagittal movement (Abello and Candela, 2010). Additionally, features associated with fast movements and leaping have been identified. In conclusion, $P$. minutus and $P$. lemoine $i$ were probably agile species with running and leaping abilities resembling Caenolestes, Lestoros, and Metachirus.

Even though the locomotor strategies described by Abello and Candela (2010) were established for only two Palaeothentes species, it may be speculated that other species of the genus, such as $P$. pascuali and $P$. intermedius, may have had similar locomotor abilities. In addition, it is possible that scansorial or arboreal locomotor behaviors evolved among non-carnivorous Santacrucian marsupials.

We note that the ecological diversity of non-caruivorons Santacrucian marsupials evaluated here is similar to that of current tropical habitats of South America (see below). In extant ecosystems, ecological diversity is positively correlated with habitat complexity (i.e. with the development of vertical strata in a habitat; August, 1983). In the case of Santacrucian marsupials, the ecological diversity inferred here would seem to reflect a vertical heterogeneity. In this context, it is possible to infer that the vertical space of these habitats could be exploited by Santacrucian marsupials through scansorial and/or arboreal habits. Vertical space offers an additional dimension for niche partitioning, and hence the possibility of more species coexisting in the same area (Miles et al., 1981; Vieira and Monteiro-Filho, 2003; Croft and Eisenberg, 2006 and references therein).

\subsubsection{Feeding habits}

According to the crown morphology of its molars, Miocene microbiotheriids were considered insectivores or insectivores/frugivores (Pascual and Bond, 1986; Goin, 1997). Based on an analysis of molar wear facets, Goin et al. (in press) concluded that Early Oligocene Patagonian members of this family (including Microbiotherium, a genus that we analyzed in this study) were insectivores.
According to our results. Miocene microbiotheriids also were mainly insectivores. Only one species, $M$. gallegosense, has shearing ratios that indicate a more limited shearing component, suggesting an insectivorous-frugivorous diel (Fig. 10.5a, b). Microbiotherium acicula is the most extreme insectivorous species, showing the highest SRL and SRA values. Microbiotherium patagonicum is closer to the extant Dromiciops gliroides in SRL values, aud it achieved a similar degree of molar crest developmeut as in the living species.

In our analysis, $D$. gliroides is grouped with insectivorous species (Fig. 10.5a, b). This result is consistent with the information of its main dietary preferences in the wild. Analysis of stomach contents indicated that this species feeds primarily on arthropods and other invertebrates (Mann, 1955; Meserve et al., 1988). However, it also feeds seasonally on fruits (Amico et al., 2009). This strategy could be extrapolated to Santacrucian microbiotheriids, as insectivores may consume plant material, either regularly or seasonally, when prey species are scarce or unavailable (Hume, 2003).

According to molar crown morphology, Miocene paucituberculatans were considered insectivores, insectivores-frugivores, and insectivores-phytophages (e.g. Ortiz-Jaureguizar, 2003). Our analysis corroborates this inference, showing that insectivores are more diverse (five species) than insectivore-frugivores and frugivores (including the insectivorous-phytophagous category of Ortiz-Jaureguizar, 2003; see above) (Table 10.1). As Dumont et al. (2000) pointed out, folivory seems not to have evolved in paucitnberculatans, as no taxon with high shearing ratios has an estimated body mass higher that $600 \mathrm{~g}$ (Smith and Lee, 1984).

Most insectivorous paucituberculatans differ inarkedly in body mass (e.g. Palaeothentes minutus, P. intermedius. and $P$. (emoinei), suggesting that ecological separation among them may have been achieved by differences in dietary composition and/or consumption of prey of different body size. In living insectivores, such as dasyurid marsupials and soricid placentals, there is a positive correlation between body size of predators and their prey (Fisher and Dickman, 1993; Churchfield et al., 1999). Even so, both small and large dasyurids can exploit a relatively large range of prey sizes, and there is no physical constraint on the size of prey consumed. Consequently, dasyurid species maximized their rates of energy intake by feeding on prey of a selected size (Fisher and Dickman, 1993). Thus, larger dasyurids prefer larger invertebrates because of greater energy return per prey item; conversely, for the smaller dasyurids prey consumption requires more chewing time, and this could result in a fall in the rate of energy intake from eacb prey (Fisher and Dickman, 1993). Despite small differences in body size and overall ecology, niche overlap is minimized in shrews as they differ in terms of the 

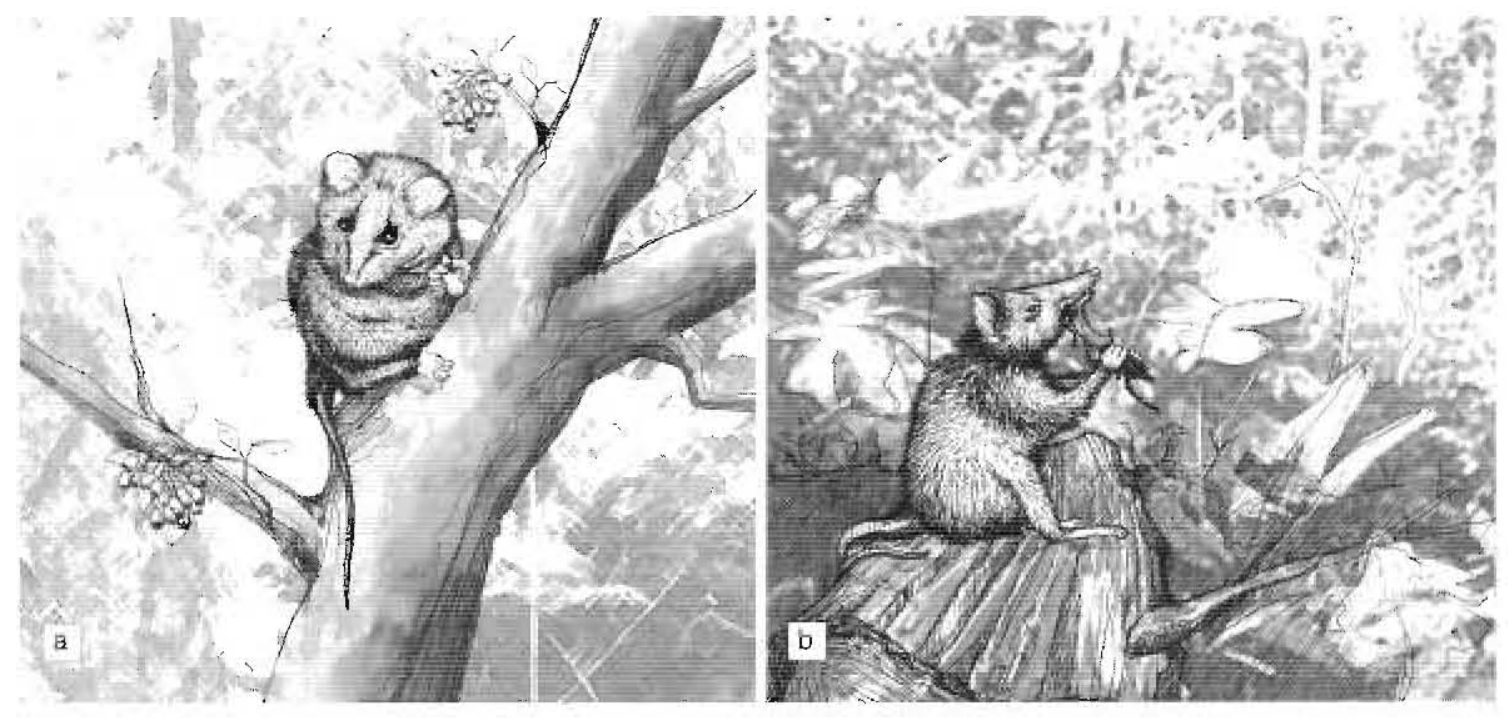

Fig. 10.7. Life reconstructions. a, Abderites meridionalis and b, Palaeothentes minutus. Drawing by Pablo Motta.

percentage of several invertebrate prey in the diet (Churchfield et al., 1999). We expect that dietary composition (as it covaries with body size) would have produced niche separation among extinct insectivorous paucituberculatans.

As mentioned above, the body mass of Santacrucian microbiotheriids and paucituberculatans overlaps to some degree in the small to medium size range (Fig. 10.6a), initially suggesting that some niche overlap may have occurred. However, differences in body size and molar morphology suggest that niche overlap was, in fact, ıninimal, and it is also possible that differences occurred not only in diet composition, but also in foraging mode (Sanson, 1985; Churchfield and Sheftel, 1994; Churchfield et al., 1999).

Frugivorous and insectivorous-frugivorous marsupials analyzed here do not exhibit body mass overlap (compare Fig. 10.6b with 10.6c). Frugivorous species are paucituberculatans belonging to Palaeothentidae (Palaeothentes aratae and Acdestis owenii. Fig. 10.2k, 1) and Abderitidae (Abderites meridionalis. Figs. $10.2 \mathrm{~m}, \mathrm{n}$ and $10.7 \mathrm{a}$ ), which are quite distinct in dental morphology (Abello, 2007). The dentition of Abderitidae is characterized by the presence of welldeveloped lophs and a plagiaulacoid complex (Simpson, 1933; Ortiz-Jaureguizar, 2003). The plagiaulacoid complex of Abderites was considered by Dumont $e t$ al. (2000) as a dietary indicator in addition to body mass and extent of molar shearing. According to their analysis, occlusion between P3 and $\mathrm{m} 1$ in Abderites was a shearing complex that operated in a manner similar to that of living Australian phalangerids such as Phalanger, but dissimilar to those of other marnmals with plagiaulacoid dentition such as certain Cretaceous to Early Eocene multituberculates (e.g. the cimolodontan Ptilodus Cope, 1881) and North American Paleocene plesiadapiform primates (e.g. Carpodaptes Mathew and Granger, 1921). In the multituberculates and plesiadapiforms, the shearing teeth mainly exhibit apical wear, because the lower cutting teetb become wom when the food is ground against a cuspate upper tooth. In contrast, in Phalanger, and probably also in Abderites, the food items are cut between the upper and lower teeth as they shear across one anotber in a scissor-like fashion (Dumont et al., 2000). A shearing complex similar to that of the abderitids occurs in many extant Diprotodonta, including the Phalanger already mentioned as well as Burramys and the Potoroidae Hypsiprymnodon and Bettongia. Related to their function, these dental modifications arc adequate to break open food items with a hard covering (Dimpel and Calaby, 1972; Parker. 1973).

On the other hand. Palaeothentes aratae and Acdestis owenii have a strong shearing crest (paracrista) ou $\mathrm{ml}$ (Fig. 10.2k, 1), but they lack a plagiaulacoid dentition and lophs. These differences suggest that frugivorous paucituherculatans were distinct not only in body mass but in their diets as well (Ortiz-Jaureguizar, 2003).

\subsubsection{Paleoenvironmental implications}

From the wide range of estimated body masses and diet of non-carnivorous Santacrucian marsupials, several ecologic niches were reconstructed: small- to medium-sized insectivores, and small to large frugivores and insectivoresfrugivores. In regard to a paleoecological reconstruction, this ecological diversity suggests the existence of forested habitats that could have supported the diverse marsupial niches. In modern ecosystems, and particularly in tropical forests, high values of mammalian species richness arise from habitat heterogencity, mainly owing to the partitioned vertical space (August, 1983; Bakker and Kelt, 2000). 
Species richness also tracks plant prodnctivity, with higher productivity leading to more species (Kay et al., 1997).

Paleoenvironmental inferences can also be advanced by analyzing the trophic guild structure of Santacrucian marsupials. In a macroecological study of Neotropical marsupials, Birney and Monjeau (2003) evaluated the latitudinal variation among several biological characters, such as trophic guild structure, habitat use, and body size. Taking into account that latitude is a surrogate for physical environmental variables sucb as temperature and precipitation, the trophic guild structure of Santacrucian marsupials may offer clues to the Santacrucian paleoenvironments. According to Birney and Monjeau (2003), three guilds were considered: frugivores, carnivores, and insectivores. Current carnivorous marsupials include, among others, the didelphids Didelphis, Lutreolina, and Philander, all of them having body masses less than $2 \mathrm{~kg}$. In the Santacrucian assemblage, carnivores with body masses less than or equal to $2 \mathrm{~kg}$ include the sparassodonts Sipalocyon gracilis Ameghino, S. obusta Ameghino. Psetudonotictis pusillus Ameghino, and Perathereutes pungens Ameghino (see Prevosti et al., Chapter 11). Thus, small carnivores represent $22 \%$ of the Santacrucian marsupial species richness, insectivore-frugivores plus frugivores $33 \%$, and insectivores $45 \%$. Comparing the trophic guild structure of Santacrucian marsupials with those of the modern Neotropics, we find that in the Santacrucian fauna there is a relatively high percentage of frugivores in relation to camivores, a ratio that occurs at low latitudes in the extant marsupial faunas of South America. Birney and Monjeau (2003) concluded that the thermal range (i.e. the difference between mean maximum extreme temperatures and mean minimum extreme temperatures) is the best predictor of the proportion of frugivores and carnivores. Closer to the equator, the narrower thermal range allows year-long availability of fruits, and the percentage of frugivores is higher than at high latitudes. Additionally, differences in precipitation (i.e. seasonal rainfall) seem to be another important factor influencing the abundance of frugivores (Birney and Monjeau, 2003). If we consider this last factor, the sharp differences between dry and wet seasons in the tropics would have allowed more diversificalion in the trophic niche than more constant precipitation. On the basis on these ecological similarities, we can infer that Santaciucian marsupials lived in relatively warm climates, but with seasonal rainfall. However, it should he kept in mind that taphonomic bias and time averaging are common factors that affect the composition of fossil assemblages. Consequently, in the absence of a precise evaluation of the incidence of these biases, the infereuces derived from a fossil assemblage have a less heuristic value that those based on living assemblages.

In summary, the ecological characteristics of non-carnivorous marsupials of the Santacrucian suggest that they lived in forested habitats developed under warm temperatures and rain seasonality. According to the fossil record of vascular plants, the distribution of megathermal and mesothermal angiosperms expanded their distribution at middle-high latitudes of Patagonia during the Late Oligocene to Early Miocene (Barreda and Palazzesi. 2007; Brea et al., Chapler 7). Nevertheless, the first records of some shrubby and herbaceous angiosperms in southern South America suggest that the vegetation acquired a more complex physiognomy than that of the Early Oligocene (Barreda and Palazzesi, 2007). During the Early Miocene, xerophytic (or mesophytic) vascular plants were dominant in Patagonia, and the development of all these specialized communities was probably related to a water deficit in open forest regions or marginal marine areas. During the late Early Miocene, rainforest trees may have formed riparian or gallery forests in central Patagonia, while drier conditions would have prevailed in lowland areas (Barreda and Palazzesi, 2007). Finally, during the latest Early Miocene, xerophytic elements suffered a geographic retraction in Patagonia, with an increase of megathermals and a dominance of aquatic herbs and hydrophytes. Forests persisted across extra-Andean Patagonia until about the Middle Miocene (Barreda, 2002; Barreda and Palazzesi, 2007; Palazzesi and Barreda, 2007).

If we consider the ecological information provided by all the Santacrucian mammals (Prevosti et al., Chapter 11; Vizcaino et al., Chapter 12; Bargo et al., Chapter 13; Cassini et al., Chapter 14; Candela et al., Chapter 15; Kay et al., Chapter 16), this fauna was dominated by grazers and mixed-feeders, with frugivores and browsers remaining highly diverse. This distribution of trophic niches indicates that during Santacrucian times a balance existed between grasslands and woodlands, probably represented by a park savanna (Webb, 1978; Pascual and Ortiz-Jaureguizar, 1990; Pascual et al., 1996; Ortiz-Jaureguizar and Cladera, 2006, and references therein). From a climatic point of view, the presence of primates and other warm climate-sensitive vertebrates that have been recorded as far south as $51^{\circ} \mathrm{S}$ suggests that warm and forested habitats were well developed in Patagonia. Nevertheless, together with these indicators of warm and forested habitats, there were also other mammals such as some rodents that indicate the existence of open habitats encroaching on areas of wet forests in Palagonia (Pascual et al., 1996; Ortiz-Jaureguizar and Cladera, 2006; Pérez, 2010).

Considering the evidence provided by vascular plants and mammals, we may conclude that the ecological diversity of the Santacrucian marsupials is compatible with the existence of habitat patchiness during Santacrucian times, with a balance between closed and open habitats represented by a park savanna. In this scenario, the non-camivorous marsupial species would have occupied the more forested areas (Fig. 10.7). 


\subsection{Conclusions}

Microbiorheria and Paucituberculata of the Santa Cruz Formation constitute an ecologically diverse assemblage of non-carnivorous marsupials. Among microbiotheriids we recoguize small insectivores such as Microbiotherium acicula and $M$. tehuelchum, and a medium-sized insectivore-frugivore, $M$. gallegosense. Compared with microbiotheriids, paucituberculatans are taxonomically and ecologically more diverse, having a wider range of body mass and diet. For this group we identify small iusectivores such as Phonocdromus gracilis, medium-sized curso-saltatorial insectivores such as Palaeothentes minutus (Fig. 10.7b) and $P$. lemoinei, the small- to medium-sized insectivoresfrugivores Stilotherium dissimile and Acdestis owenii, the medium-sized frugivore Abderites meridionalis (Fig. 10.7a), and the large frugivore Palaeothentes aratae.

Regarding the marsupials of the insectivore guild, a minimal niche overlap was inferred from differences in body mass and its relations to prey size and diet composition, as is observed in extant insectivorous Inammals. In addition to the inferred terrestrial, curso-saltatorial locomotion of Palaeothentes minutus and $P$. lemoinei, scansorial or arboreal locomotor behaviors could have evolved among noncarnivorous Santacrucian marsupials that allowed their exploitation of resources in the vertical space.
From the present study, the ecological diversity of the non-camivorous Santacrucian marsupial indicates that they lived in forested habitats, under warm temperatures aud rain seasonality. Forested habitats could have supported the vatied previously mentioued marsupial niches, offering diverse resources in the spatial and trophic dimensions. Considering also the paleoecological iuformation provided by vascular plants and all the mammalian species, we conclude that the ecological diversity of non-carnivorous marsupials is compatible with a patchy environment, with a balance between vegetation typical of closed and open habitats, represented by a park savanna.

ACKNOWLEDGMENTS

We thank D. Flores (MACN), A. Kramarz (MACN), and M. Reguero (MLP) for facilitating access to specimens of marsupials in their care, and F. Goin (MLP) for allowing us to study specimens in his personal collection. Special thanks to the editors of this volume, S. F. Vizcaino, R. F. Kay, and M. S. Bargo, for inviting us to make this contribution, and ro P. Posadas (LASBE-MLP) and C. Morgan for their help with the English version. This is a contribution to the projects PICT 0143 to Sergio F. Vizcaino and NSF 0851272,0824546 to Richard F. Kay. 


\section{Appendix 10.1 Paucituberculata and Microbiotheria of the Santa Cruz Formation}

Microbiotheria Ameghino, 1889

Microbiotheriidae Ameghino, 1887

Microbiotherium acicula (Ameghino, 1891)

Microbiotherium patagonicum Ameghino, 1887

Microbiotherium tehuelchum Ameghino, 1887

Microbiotherium gallegosense Sinclair, 1906

Paucituberculata Ameghino, 1894

Caenolestidae Trouessart, 1898

Stilotherium dissimile Ameghino, 1887

Pichipilidae (Marshall, 1980)

Phonocdromus gracilis Ameghino, 1894

Palaeothentidae Sinclair, 1906

Palaeothentes aratae Ameghino, 1887

Palaeothentes minutus Ameglino, 1887

Palaeothentes intermedius Ameghino, 1887

Palaeothentes lemoinei Ameghino, 1887

Palaeothentes pascuali Bown and Fleagle, 1993

Acdestis owenii Ameghino, 1887

Acdestis lemairei Bown and Fleagle, 1993

Abderitidae (Ameghino, 1889)

Abderites meridionalis Ameghino, 1887

List of Paucituberculata and Microbiotheria from localities of the Santa Cruz Formation

For details of the specimens. localities, data of collection and collectors (Col.) see Marshall (1980, 1982), Bown and Fleagle (1993) and Vizcaíno et al. (Chapter 1: Figs. 1.1 and 1.2, and Appendix 1.1).

Gobernador Gregores: Acdestis owenii.

Lago Cardiel: Acdestis owenii.

Río Chalía - Ea. Viven Aike - (Col. Bown y Fleagle):

Palaeothentes minutus, Palacothentes intermedius, Acdestis owenii, Acdestis lemairei.
Monte León (Col. Bown and Fleagle): Palaeothentes ararae. Palaeothentes minutus, Palaeothentes intermedius, Palaeorhentes lemoinei, Acdestis owenii, Acdestis lemairei. La Cueva (Col. Ameghino): Phonocdromus gracilis, Palaeothentes minutus, Palaeothentes intermedius, Palaeothentes lemoinei, Stilotherium dissimile, Abderites meridionalis, Microbiotherium patagonicum, Microbiotherium tehuelchum.

Yegua Quemada (Col. Ameghino): Palaeothentes intermedius, Palaeothentes lemoinei, Microbiotherium tehuelchum.

Santa Cruz (Col. Ameghino): Palaeothentes aratae. Palaeothentes minutus, Palaeolhentes lemoinei, Microbiotherium patagonicum.

Monte Observación (= Cerro Observatorio. see Marshall, 1976b, and Vizcaíno et al., Chapter !; Col. Ameghino, Bown and Fleagle): Palaeothentes aratae, Palaeothentes minutus, Palaeothentes pascuali. Palaeothentes intermedius, Palaeothentes lemoinei, Stilotherium dissimile. Abderites meridionalis, Acdestis owenii, Acdestis lemairei, Microbiotherium acicula, Microbiotherium patagonicum. Microbiotherium tehuelchum.

Puesto Estaucia La Costa (= Corriguen-Aike; Col. MLPDuke University): Palaeothentes lemoinei.

Corriguen-Kaik (Col. Ameghino): Palaeothentes lemoinei, Microbiotherium tehuelchun.

Killik-Aike (Col. H. Felton): Palaeothentes minutus, Microbiotherium tehuelchum.

Río Gallegos (Col. B. Brown): Palaeorhentes aratae. Palaeothentes minutus.

Near Feitou's Estaucia, along the uorth bank of the Rio Gallegos (Col. Bamum Brown): Phonocdromus gracilis. Microbiotherium acicula, Microbiotherium gallegosense.

Sehuen (= Río Chalía; Col. Ameghino): Palaeothentes aratae, Palaeothentes lemoinei, Palaeothentes intermedius, Stilotherium dissimile. Abderites meridionalis, Micrebiotherium patagonicum. 


\section{Appendix 10.2 Material studied}

\section{Microbiotheriidae}

Microbiotherium acicula (Ameghino. 1891),

MACN-A 5727, a left mandibular ranus with p3-m4. Horizon and locality: Santa Cruz Formation, Monte Observación, Santa Cruz Province.

Microbiotherium patagonicum Ameghino, 1887

MLP 11-30, a right mandibular ramus with in 1-4. Horizon and Iocality: Santa Cruz Formation, collected from "las barrancas del róo Santa Cruz" (Ameghino. 1889: 264). Santa Cruz Province.

Microbiotherium tehuelchum Ameghino, 1887

MLP 11-36, a right mandibular ramus with $\mathrm{p} 2-\mathrm{m} 4$. Horizon and locality: Santa Cruz Formation, without locality data (see Marshall. 1982), Santa Cruz Province.

Microbiotherium gallegosense Sinclair, 1906

AMNH 9591, a right mandibular ramus with p3-in2. Horizon and locality: Santa Cruz Formation, Estancia Felton, Santa Cruz Province.

Dromiciops gliroides Thomas, 1894

MACN 19142, MACN 22918, MACN 22919, and MACN 13038.

\section{Paucituberculata}

Abderites meridionalis Ameghino, 1887

MACN-A 5542, left mandibular ramus with $\mathrm{ml}-4$ and MACN-A 2037, left mandibular ramns with p3-m4. Horizon and locality: Santa Cruz Formation, Monte Observación, Santa Cruz Province; MACN-A 5541, left mandibular ramus with $\mathrm{p} 3-\mathrm{m} 4$ and $\mathrm{PU} 15079$, left mandibular ramus with p3-m3. Horizon and locality: Santa Cruz Fonnation, Río Chalía, Santa Cruz Province; MACN-A 8248, left mandibular ramus with p3-1n3. Hoizzon and Iocality: Santa Cruz Formation, La Cueva, Santa Cruz Province; MACN-A 2031, left mandibular ramus with $\mathrm{m} 2$ : MACN-A 2032, right mandibular ramus with m2-4; MACN-A 2033, right mandibular ramus with $\mathrm{m} 2-4$; MACN-A 2034. right mandibular ranus with $\mathrm{m} 1-3$; MLP 11-109, right mandibular ramus with $\mathrm{ml}-2$; MLP 11-133, left mandibular ramus with m2-3; MLP 55-XII-13-144. right mandibular ramus with $\mathrm{m} 2$; and MACN 11651, right mandibular xamus with p3-m4. Horizon and locality: unknown, Santa Cruz Province.

\section{Palaeothentes minutus}

MACN-A 5619-5639a-I, right and left mandibular rami with $\mathrm{m} 3-4$, distal portion of right humerus, proximal portion of right ulna, partially complete pelvis, proximal portion of right femur, proximal portion of left femur, and right calcaneum. Horizon and locality: Santa Cruz Formation, Killik-Aike, Santa Cruz Province.

\section{Palaeothentes lemoinei}

MPM-PV 3494, right mandibular fragınent with $m 2-4$ and left edentulous mandibular fragment, left humerus, left ulna, left fragment of pelvis, fragment of right tibia, fragment of left tibia, and right astragalus. Horizon and locality: Santa Cruz Formation, Estancia La Costa Member, Fossiliferous Level 5.3, Puesto Estancia La Costa, Santa Cruz Province.

\section{REFERENCES}

Abello, M. A. (2007). Sistemática y bioestratigrafía de los Paucituberculata (Mammalia, Marsupialia) del Cenozoico de América del Sur. Unpublished Ph.D. thesis, Universidad Nacional de La Placa, Argentina.

Abello, M. A. and Candela, A. M. (2010). Postcranial skeleton of the Miocene marsupial Palaeothenies (Paucituberculata, Palaeothentidae): paleobiology and phylogeny. Jownal of Vertebrate Paleontology. 30, 1515-1527.

Abello, M. A. and Rubilar-Rogers. D. (in press). Revisión del género Abderites Ameghino, 1887 (Marsupialia, Paucisuberculala). Ameghiniana.

Albuja, L. and Pallerson, B. D. (1996). A new species of northem shrew-opossum (Paucituberculata: Caenolestidae) from the Cordillera del Cóndor, Ecuador. Journal of Mammalogy, $77,41-53$.

Ameghino, F. (1887). Enumeración sistemática de las especies de mamíferos fósiles coleccionados por Carlos Ameghino en los terrenos eocenos de la Patagonia austral. Boletín del Museo de La Plara, 1. 1-26.

Ameghino, F. (1889). Contribución al conocimiento de los mamíferos fósiles de la República Argentina. Actas de la Academia Nacional de Ciencias de Córdoba, 6 , XXXIII- 1027.

Ameghino, F. (1891). Nuevos restos de mamíferos fósiles descubiertos por Carlos Ameghino en el Eoceno inferior de Patagonia austral. Especies nuevas, adiciones y 
correcciones. Revista Argentina de Historia Natural, 1, 289-328.

Amico, G. C.. Rodríguez-Cabal, M. A. and Aizen, M. A. (2009).

The potential key seed-dispersing role of the arboreal marsupial Dromiciops gliroides. Acta Decologica. $35,8-13$.

Amrine-Madsen, H., Scally, M., Westerman, M. et al. (2003). Nuclear gene sequences provide evidence for the monophyly of australidelphian marsupials. Molectular Phylogenetics and Evolution, 28, 186-196.

Anderson, S. (1997). Mammals of Bolivia, taxonomy and distribution. Bulletin of the American Museum of Nafural History, 231, 1-652.

Argot, C. (2003a). Postcranial funcrional adaptations in the South American Miocene borhyaenoids (Mammalia, Metatheria): Cladosictis, Pseudonotictis and Sipalocyon. Alcheringa, 27, 303-356.

Argot, C. (2003b). Functional adaptations of the postcranial skeleton of two Miocene borhyaenoids (Mammalia. Metatheria), Borhyaena and Prothylaeinus, from South Anerica. Palaeontology, 46, 1213-1267.

Asher, R. J., Horovitz, I. and Sánchez-Villagra, M. R. (2004). First combined cladistic analysis of marsupial mammal interrelationships. Molecular Phylogenetics and Evolution, $33,240-250$.

August, P. V. (1983). The role of habitat complexity and heterogeneity in structuring tropical mammal communities. Ecology, 64 (6), 1495-1507.

Bakker, V.J. and Kelt, D. A. (2000). Scale-dependent patterns in body size distributions of Neotropical mammals. Ecology. 81, 3530-3547.

Barkley, L. J. and Whitaker, J. O. Jr. (1984). Confimation of Caenolestes in Peru with information on diet. Journal of Mammalogy, 65, 328-330.

Barreda, V. D. (2002). Palinofloras cenozoicas. In Geología y Recursos Naturales de Santa Cruz, Relatorio del XV Congreso Geológico Argentino, ed. M. 犭. Hal!er. Buenos Aires: Asociación Geológica Argentina, pp. 545-567.

Barreda, V. and Palazzesi, L. (2007). Patagonian vegetation tumovers during the Paleogene-early Neogcne: origin of arid-adapted floras. The Botanical Review, 73, 3i-50.

Beck, R. M. D. (2008). A dated phylogeny of marsupials using a molecular supermatrix and multiple fossil constraints. Journal of Mammalogy, 89. 175-189.

Bimey, E. C. and Monjeau, J. A. (2003). Latitudinal variation in South American marsupial biology. In Predators with pouches: the biology of carnivorous marsupials, ed. M. Jones, C. Dickman and M. Acher. Hobart, Australia: CSIRO Publishing, pp. 297-317.

Bimey, E. C., Sikes. R. S., Monjeau. J. A., Guthmann, N. and Carleton, J. P. (1996). Comments on Paragonian marsupials of Argentina. In Contrihution in Mamnalogy, A Memorial Volume Honoring Dr. J. Knox Jones Jr.. ed. H. H. Genoways aud R. J. Baker. Museum of Texas Tech University Press, pp. 149-154.

Bown, T. M. and Fleaglc. J. G. (1993). Sysrematics, biostratigraphy, and dental evolution of the Palaeothentidae, later Oligocene to Early-Middle Miocene (Deseadan-Santacrucian) Caenolestoid Marsupials of South America. Journal of Palacontology Menoir 29, 67, 1-76.

Bozinovic, F., Ruiz, G. and Rosenınann, M. (2004). Energerics and torpor of a South American "living fossil", the microbiotheriid Dromiciops gliroides. Journal of Comparative Physiology B, 174, 293-297.

Charles-Dominique, P. (1983). Ecology and social adaptation in didelphid marsupials: comparisons with eutherians of similar ecology. In Adrances in the Study of Mammalian Behavior, ed. J, F. Eisenberg. Shippensburg: American Society of Mammalogist, pp. 305-422.

Charles-Dominique, P., Atramentowicz, M., Charles-Dominique, M. ef al. (1981). Les mammiferes frugivores arboricoles nocturnes d'une foret guyanaise: inter-relations plantesanimaux. Revue d'Ecologie (Terre Vie) 35, 341-436.

Churchfield, S. and Sheftel. B. I. (1994). Food niche overiap and ecological scparation in a multi-species community of shrews in the Siberian taiga. Journal of Zoology, 234. 105-124.

Churchifield, S., Nesterenko V.A. and Shvarts, E. A. (1999). Food niche overlap and ecological separation amongst six species of coexisting forest shrews (Insectivora: Soricidae) in the Russian Far East. Joumal of Zoology, 248, 349-359.

Croft. D. B. and Eisenberg, J. F. (2006). Behaviour. In Marsupials, ed. P. J Armati, C. R, Dickman and I. D Hume. Cambridge, UK: Cambridge University Press, pp. 229-298.

Delciellos, A. C. and Vieira, M. V. (2006). Arboreal walking performance in seven didelphid marsupials as an aspect of their fundamental niche. Austral Ecology, 31, 449-457.

Delcielios, A. C. and Vieira, M. V. (2009). Jumping ability in the arboreal locomotion of didelphid marsupials. Mastozoología Neotropical. 16, 299-307.

Dickman. C. R. and Vieira, E. (2006). Ecology and life histories. In Marsupials, ed. J. P. Armati. C. R. Dickman and I. D. Hume. Cambridge: Cambridge University Press, pp. 199-228.

Dimpel, H. and Calaby, J.H. (1972). Further observations on the mountain pygmy-possum (Burramys parvus). Victorian Naturolist, 89, 101-106.

Dumont, E. R., Strait, S. G. and Friscia, A. R. (2000). Abderitid marsupials from the Miocene of Patagonia: an assessment of form, function, and evolution. Journal of Paleontology, 74, 1161-1172.

Fisher, D. O. and Dickman, C. R. (1993). Body size-prey size relationships in insectivorous marsupials: tests of three hypotheses. Ecology, 74. 1871-1883.

Flores, D. A. (2006a). Orden Paucituberculata Ameghino, 1894. In Mamiferos de Argentina. Sistemática y Distribuctón. ed. R. M. Bárquez, M. M. Díaz and R. A. Ojeda. Tucumán: SAREM, p. 45.

Flores, D. A. (2006b). Orden Microbiotheria Aıneghino, 1897. In Mamiferos de Argentina. Sistemática y Distribución. ed. R. M. Bárquez, M. M. Díaz and R. A. Ojeda. Tucumán: SAREM, p. 46. 
Goin, F. J. (1997). New clues for understanding Neogene marsupial radiations. In A History of the Neotropical Fauna. Vertebrate Paleobiology of the Miocene in Colombia, ed. R. F. Kay, R. H. Madden, R. L. Cifelli and J. J. Flynn. Washington: Smithsonian Institution Press, pp. 185-204.

Goin, F. J. (2003). Early marstipial radiations in South America. In Predators with Pouches: The Biology of Cannorous Marsupials, ed. M. Jones, C. Dickman and M. Acher. Hobart, Anstralia: CSIRO Pnblishing, pp. 30-42.

Goin, F. J., Candela, A. M., Abello, A. and Oliveira, E. O. (2009). Earliest Sourh American Paucituberculatans and their significance in the understanding of "pseudodiprotodont" marsupial radiations. Zoological Jounal of the Linnean Society, 155, 867-884.

Goin, F. J., Abello, M. A. and Chomogubsky, L. (2010). Middle Tertiary marsnpials from central Patagonia (early Oligocene of Gran Baranca): understanding South America's grande coupure. In The Paleontology of Gran Barranca: Evolution and Environmental Change through the Middle Cenozoic of Patagonia, ed. R.H. Madden, A. A. Carlini, M. G. Vucetich and R. F. Kay. Cambridge: Cambridge University Press. pp. 69-105.

Goin, F. J., Zimicz, A. N., Forasiepi, A. M., Chornogubsky, L. and Abello, M.A. (in press). The rise and fall of South American Metatherians: contexts, adaptations, radiations, and extinctions. In Origins and Evolution of Cenozoic South American Mammals. ed. A. L. Rosenberger and M. F. Tejedor. Verrebrate Paleohiology and Paleoanthropology series. Dordrecht: Springer.

Grand. T. I. (1983). Body weight: its relationship to tissue composition, segmental distribution of mass and motor function. III. The Didelphidae of French Guyana. Australian Journal of Zoology, 31, 299-312.

Greer, J.K. (1966). Mammals of Malleco Province, Chile. Publications of the Museum of the Michigan State University (Biological Series), 3, 49-152.

Heesy, C. P. (2008). Ecomorphology of orbit oricntation and the adaptive significance of biuocular vision in primates and other mammals. Brain, Behavior and Evolution, 71, 54-67.

Hershkovitz. P. (1999). Dromiciops gliroides Thomas, 1894, last of the Microbiotheria (Marsupialia), with a rcview of the family Microbiotheriidae. Ficldiana Zoology (new series), 93, 1-60.

Horovitz, I. and Sánchez-Villagra, M. R. (2003). A morphological analysis of marsupial mammal higher-level phylogenetic relationships. Cladistics, 19, 181-212.

Hume, I. D. (2003). Nutrition of carnivorous marsupiais. In Predators with pouches: the biology of carnivorous marsupials, ed. M. Jones, C. Dickman and M. Acher. Hobart. Australia: CSIRO Publishing, pp. 221-228.

Hume, I. D. (2006). Nutrition and digestion. In Marsupials, ed. J.P. Armari, C. R. Dickman and I. D. Hume. Cambridge: Cambridge University Press, pp. 137-158.

Kay, R. F. and Hiiemae, K. (1974). Masticalion in Galago crassicandatus: a cineflourographic and occlusal study. In Prosimian biology, ed. R. D. Martin, G. A. Doyle, and
A. C. Walker. Pittsburgh: University of Pittsburgh Press, pp. 501-530.

Kay, R.F. and Hylander, W. L. (1978). The dental suncture of mammalian folivores with special reference to primates and Phalangeroidea (Marsnpialia). In The Ecology of Arboreal Folivores, ed. G. G. Montgomery. Washington D.C.: Smithsonian Institution Press, pp. 173-191.

Kay, R.F., Madden, R. H., Van Schaik, C. and Higdon, D. (1997). Primate species richness is determined by plant productivity: Implications for conservation. Proceedings of the National Academy of Sciences. USA, 94, 13023-13027.

Kelt, D. A., Meserve, P. L. and Lang, B. K. (1994). Quantitative habirat associations of small mammals in a remperate rainforest in sonthern Chile: empirical patterns and the importance of ecological scale. Journal of Mammalogy, 75, 890-904.

Kirsch, I. A. W. and Waller, P. F. (1979). Notes on the trapping and behavior of the Caenolestidae (Marsupialia). Journal of Mammalogy, 60, 390-395.

Lee, A. K. and Cockburn, A. (1985). Evolutionary Ecology of Marsupials. Cambridge: Cambridge Universiry Press.

Mann, G. (1955). Monito del monte Dromiciops australis Philippi. Investigaciones Zoologicas Chilenas, 2, 159-166.

Marshall, L. G. (1976a). Revision of the South American Fossil Marsupial subfamily Abderilinae (Mammalia, Caenolestidae). Publicaciones del Museo Municipal Ciencias Naturales "Lorenzo Scaglia," 2, 57-90.

Marshall, L. G. (1976b). Fossil localities for Santacrucian (early Miocene) mammals, Santa Cruz Province, southern Patagonia, Argentina. Journal of Paleontology, 50, $1129-1142$.

Marshall, L. G. (1980). Systematics of the South American marsupial fainily Caenolestidae. Fieldiana Geology (new series), 5, 1-145.

Marshall, L. G. (1982). Systematics of the South American marsupial family Microbiotheriidae. Fieldiana Geology, $10,1-75$.

Meredith, R. W., Westerman, M., Case, J.A. and Springer, M. S. (2008). A phylogeny and timescale for marsupial evolntiou based on sequences for five nuclear genes. Journal of Mammalian Evolution, 15, 1-26.

Meserve, P. L., Lang, B. K. and Patterson, B. D. (1988). Trophic relationships of small mammals in a Chilean temperate rain forest. Journal of Mammalogy, 69, 721-730.

Miles. M. A., Sousa, A. A. and Póvoa, M. M. (1981). Mammal tracking and nest Jocation in Brazilian forest with an improved spool-and-line device. Joumal of Zoology, 195, 331-347.

Miranda, C. L., Rossi, R. V., Silva Júnior, J. S., Lima, M. G. M. and Santos, M.P. D. (2009). Mammalia, Didel phimorphia, Didelphidae, Metachirus midicaudatus, Municipality of José de Freitas, State of Piauí, Northeastem Brazil: Distribution extension. Check List, 5, 360-363.

Moraes, E. A. Jr. (2004). Radio tracking of one Metachirus nudicaudatus (Desmarest. 1817) individual in Atlantic Forest of Southeastem Brasil. Boletim do Museu de Biologia Mello Leitão, 17, 57-64. 
Nilsson, M., Amason, U., Spencer, P. B. S. and Janke, A. (2004). Marsupial relationships and a limeline for marsupial radiation in South Gondwana. Gene, 340, 189-196.

Nilsson. M. A., Churakov, G., Sommer, M. et al. (2010). Tracking Marsupial evolution using archaic genomic retroposon insertions. Plos Biology, 8. e1000436.

Oriz-Jaureguizar, E. (2003). Relacioues de similitud, paleoecología y extinción de los Abderitidae (Marsnpialia, Paucituberculata, Caenolestoidea). Coloquios de Paleontología (Vol. Extr.), 1, 475-498.

Ortiz-Jaureguizar, E. and Cladera. G. (2006). Paleoenvironmental evolution of southem South America during the Cenozoic. Journal of Arid Environments, 66, 489-532.

Palazzesi, L. and Barreda, V. (2007). Major vegeration trends in the Tertiary of Patagonia (Argentina): a qualitative paleoclimatic approach based on palynological evidence. Flora. 202, 328-337.

Parker, S. A. (1973). An annotated checklist of the mammals of the Northern Territory. Records of the South Australian Museum, 16, 1-57.

Pascual, R. and Bond, M. (1986). Evolución de los inarsupiales cenozoicos de Argentina. IV Congreso Argentino de Paleontología y Bioestratigrafía, Mendoza, Actas 2. 143-150.

Pascual, R. and Ortiz-Jaureguizar, E. (1990). Evolving climates and inammal faunas in Cenozoic South America. Journal of Human Evolution, 19, 23-60.

Pascual, R., Ortiz-Jaureguizar, E. and Prado, J. L. (1996). Land mammals: Paradigm of Cenozoic South American geobiotic evolution. In Contrihution of Southern South America to Vertebrate Paleontology, ed. G. Arratia. München: Müncher Geowissenscaftliche Ab̀handlungen (A) Verlag Dr. Fiedrich Pfeil, 30, pp. 265-319.

Patterson, B. D. (2007). Order Paucituberculata Ameghino, 1894. fn Mammals of South America, Vol. 1. Marstuials. Xenarthrans, Shrew's, and Bats, ed. A. L. Gardner: Chicago and London: University of Chicago Press, pp. 119-127.

Patterson, B. D. and Gallardo, M. H. (1987). Rhyncholestes raphanurus. Mammalian Species, 286, 1-5.

Patterson, B. D. and Rogers, M. A. (2007). Order Microbiotheria Ameghino, 1889. In Mammals of South America. Vol. I, Marsupials, Xenarthrans, Shrew's, and Bats, ed. A. L. Gardner. Chicago and London: University of Chicago Press, pp. 117-119.

Pérez, M. A. (2010). Sistemática, ecología y bioestratigrafía de Eocardiidae (Rodentia. Hystricognathi, Carioidea) del Mioceno temprano y medio de Patagonia. Unpublished Doctoral thesis, Universidad Nacional de La Plata.

Phillips, M. J., McLenachan, P. A., Down. C.. Gibb, G. C. and Penny, D. (2006). Combined mirochoudrial and nuclear DNA sequences resolve the interrelations of the major Australasian marsupial radiations. Swstemaric Blology: 55. 122-137.

Ramirez, O., Arana. M., Bazán. E., Ramirez, A. and Cano, A. (2007). Assemblages of birds and mammals communities in two major ecological units of the Andean highland plateau of southern Peru. Ecologia Aplicada, 6, 139-148.
Rodríguez-Cabal, M. A., Amico, G. C., Novaro, A. J. and Aizen, M. A. (2008). Population characteristics of Dromiciops gliroides (Philippi, 1893), an endemic Inarsupial of the temperate forest of Patagonia. Mammalian Biology, 73, 74-76.

Sanson, G. D. (1985). Functional dental morphology and diet selection in dasyurids (Marsupialia: Dasyuridae). Australian Marmalogy, 8, 239-247.

Simpson, G. G. (1933). The "Plagiaulacoid" type of mammalian dentition. Journal of Mammalogy. 14, 97-107.

Sinclair, W. J. (1906). Marsupialia of the Santa Cruz beds. In Reports of the Princeton University Expeditions of Patagonia 1896-1899. Vol. 4. Palaeontology 1. Part 3, ed. W. B. Scott. Princeton: Princeton Universily Press, pp. $333-460$.

Smich, A. P. and Lee, A. (1984). The evolution of strategies for survival and reproduction in possums and gliders. In Possums and Gliders, ed. A. Smith and I. Hume. Chipping Norton, Australia: Surrey Beatty and Sons, pp. 17-34.

Staver, C. A., Bond, W. J., Stock, W. D., van Rensbnrg, S. J. and Waldram, M.S. (2009). Browsing and hre interact to suppress tree density in an African savanna. Ecological Applications, 19 (7), 1909-1919.

Strait, S. G. (1993a). Differences in occlusal morphology and molar size in frugivores and faunivores. Journal of Human Evolution, 25, 471-484.

Strait, S. G. (1993b). Molar morphology and food texture among small bodied inseetivorous mammals. Iournal of Mammalogy, 74, 391-402.

Szalay. F. S. (1982). A new appraisal of marsupial phylogeny and classification. In Camnorous Marsupials, ed. M. Archer. Sydney, Australia: Royal Zoological Society of New South Wales, pp. 621-640.

Szalay, F.S. (1994). Evolutionary History of the Marsupials and an Analysis of Osteological Characters. New York: Cambridge University Press.

Szalay, F. S. and Sargis, E. J. (2001). Model-based analysis of postcranial osteology of marsupials from the Paleocene of Itaboraí (Brazil) and the phylogenetics and biogeograpby of Metatheria. Geodiversitas, 23, 139-302.

Tauber, A. A. (1997). Paleoecología de la Formación Santa Cruz (Mioccno Iuferior) en el extremo sudeste de la Patagonia. Ameghiniana, 34, 517-529.

Vieira, E. M. and Asiúa de Moraes, D. (2003). Camivory and insectivory in Neotropical marsnpials. In Predators with pouches: the biology of carnivorous marsupials, ed. M. Jones, C. Dickman and M. Acher. Hobart. Australia: CSIRO Publishing, pp. 267-280.

Vieira, E. M. and Monteiro-Filho, E. L. A. (2003). Vertical stratification of small mammals in the Atlantic rain forest of south-eastern Brazil. Journal of Tropical Ecology, 19 , 501-507.

Webb, S. D. (1978). A history of savanna vertebrales in the New World. Part II: South America and the Greal Interchange. Annual Review of Ecology and Systematics. 9, 393-426. 